\title{
MINERAL AND ORGANOMINERAL SOURCES OF NITROGEN TO MAIZE AGRONOMIC PERFORMANCE
}

\author{
FONTES MINERAIS E ORGANOMINERAIS DE NITROGÊNIO PARA \\ AUMENTAR O DESEMPENHO AGRONÔMICO DO MILHO
}

\author{
Marcelo Alves da Rocha DIAS ${ }^{1}$; Regina Maria Quintão LANA ${ }^{2}$; José Geraldo MAGESTE ${ }^{2}$; \\ Odair José MARQUES ${ }^{3}$; Adriane de Andrade SILVA ${ }^{3}$; Ernane Miranda LEMES ${ }^{4}$; \\ Daniel Martins da SILVA ${ }^{5}$; Jéssica Mieko Ota ALVES ${ }^{5}$ \\ 1. Mestre em Agronomia Instituto de Ciências Agrárias da Universidade Federal de Uberlândia-ICIAG-UFU, Uberlândia, MG, \\ Brasil.mardias@ufu.br; 2. Professor do ICIAG-UFU, Uberlândia, MG, Brasil; 3. Professor do ICIAG-UFU, Monte Carmelo, MG, \\ Brasil; 4. Pós-doutorando na Universidade Federal de Uberlândia-ICIAG-UFU, Uberlândia, MG, Brasil; 5. Técnico de Laboratório do \\ ICIAG-UFU, Uberlândia, MG,Brasil.
}

\begin{abstract}
Nitrogen $(\mathrm{N})$ is one of the nutrients absorbed in great quantity by maize crop. Also, $\mathrm{N}$ fertilizers are of high costs and subject to large losses into the agricultural environment. There are various categories of fertilizers known as fertilizers of improved efficiency that can minimize such $\mathrm{N}$ losses. The objective of this study was to evaluate the effect of different sources and doses of $\mathrm{N}$ in maize agronomic performance. The experiment was installed in randomized blocks, with four replications, designed as a factorial $5 \times 5+1$, constituted by five $\mathrm{N}$ sources (urea, urea polymerized, urea with NBPT, organomineral with and without NBPT), five $\mathrm{N}$ doses $\left(40,80,120,160,200 \mathrm{~kg} \mathrm{ha}^{-1}\right.$ ) plus a control (no N supply). The chlorophyll contents and grain yield were evaluated. The results showed no differences for the different $\mathrm{N}$ sources, indicating that the organomineral sources are as efficient as the mineral sources. The addition of $\mathrm{N}$ fertilizers in increasing doses, regardless of the source tested, has increased the levels of chlorophylls and grain yiled.
\end{abstract}

KEYWORDS: Zea mays L.. Fertilizer technology. Grain yield. Urea. Organomineral.

\section{INTRODUCTION}

Maize (Zea mays L.) is one of the main cereals produced in the world. Its economic importance is due to its many uses from food to high-tech industry. Given the importance of this crop, farmers must treat the agronomic managements with caution, especially regard to mineral nutrition.

Among the essential mineral nutrients, nitrogen $(\mathrm{N})$ is considered one of the most demanded by maize plants because it is in the composition of proteins, enzymes, coenzymes, nucleic acids, phytocromes and chlorophylls (BÜLL, 1993). Nitrogen deficiency during any crop stage is highly damaging to crop development, and its inadequate supply and low soil levels are limiting factors to lower maize grain production.

The soil $\mathrm{N}$ availability is mainly controlled by the mineralization of organic matter and by nitrogen fertilization (ALVA et al., 2016). A low organic matter level in soil is a common condition in the Brazilian Cerrado biome (Savannah like biome), which holds most of the agricultural production area in countries like Brazil. In these soils, nitrogen fertilization becomes an essential practice to achieve high productive levels (SILVA et al., 2005). The amount, timing and precise location of the $\mathrm{N}$ fertilization is essential for a profitable maize grain production.

The $\mathrm{N}$ fertilizers are mainly produced from non-renewable fossil fuels and, when used in large quantities or in inadequate field conditions, they may lose $\mathrm{N}$ through erosion, leaching, denitrification and volatilization (LARA CABEZAS et al., 2000). A strategy to improve $\mathrm{N}$ fertilizations efficiency and losses is through the use of improved fertilizers.

Slow release fertilizers (release $\mathrm{N}$ during several months), and controlled and stabilized fertilizers (fertilizers containing inhibitors of urease and nitrification) are widespread improved fertilizers for sustainable farming (TRENKEL, 2010). Common slow release fertilizers are the fertilizers coated with polymers that hinder fertilizer solubilization in soil solution; common stabilized fertilizer containing inhibitors of urease, as NBPT (N-(n-butyl) thiophosphoric triamide), reduces the activity of this enzyme responsible to hydrolyzes urea to volatile ammonia $\left(\mathrm{NH}_{3}\right)$ (KRAJEWSKA, 2009).

Thus, the objective of this work was to evaluate the effect of different $\mathrm{N}$ sources, minerals and organomineral, with different technologies and 
Mineral and organomineral...

levels, in agronomic aspects of maize cultivated in the region of the Brazilian Cerrado.

\section{MATERIAL AND METHODS}

\section{Experimental area and study design}

The field experiment was conducted in 2015/1 in Monte Carmelo city, Minas Gerais state, Brazil, at the experimental area of the Federal University of Uberlândia (latitude: $18^{\circ} 44^{\prime} 5^{\prime \prime} \mathrm{S}$, longitude: $\left.47^{\circ} 29^{\prime} 47^{\prime \prime} \mathrm{W}\right)$. Terrain altitude is about $890 \mathrm{~m}$ from sea level, and climate is an Aw (tropical with dry winter), according to the Köppen climate classification (ALVARES et al., 2013). The soil of the experimental area is classified as a dystrophic red Latosol (EMBRAPA, 2013).

Prior to implementation of the experiment the experimental area remained for three years under grass (Brachiaria decumbens). The soil chemical characteristics and texture were: $\mathrm{pH}$ $\left(\mathrm{H}_{2} \mathrm{O}\right)$ : 5.7; P (Mehlich): $17.9 \mathrm{mg} \mathrm{dm}^{-3} ; \mathrm{K}: 187 \mathrm{mg}$ $\mathrm{dm}^{-3} ; 2.1,0.7,0,3.6 \mathrm{cmolc} \mathrm{dm}^{-3}$, respectively, for $\mathrm{Ca}, \mathrm{Mg}, \mathrm{Al}, \mathrm{H}+\mathrm{Al} ; 48 \%$ base saturation; soil organic matter: $4.2 \mathrm{dag}^{-1}$, and 54\% clay (EMBRAPA, 2011).

The experiment was carried out in a randomized block design (RBD) with four replications. The treatments were distributed as the factorial scheme: $5 \times 5+1$ control, with the first factor as five $\mathrm{N}$ fertilizer sources [urea, urea polymerized, urea with NBPT, organomineral with NBPT, organomineral without NBPT)] and the second factor as five $\mathrm{N}$ doses $(40,80,120,160,200$ $\mathrm{kg} \mathrm{ha}^{-1} \mathrm{~N}$ ) - all ureias used had $45 \% \mathrm{~N}$ and the organomineral source was equivalent to the formulation 26-0-0 (NPK). The treatments application (sidedressing) was performed 34 days after sowing when plants were awarded V4 stage. The control treatment consisted of no $\mathrm{N}$ application.

The NPK sowing fertilization was indicated by the Minas Gerais state recommendations for maize crop (ALVES et al., 1999). The P source used was the mono-ammonium phosphate $(49 \%$ $\left.\mathrm{P}_{2} \mathrm{O}_{5} ; 10 \% \mathrm{~N}\right)$ at $70 \mathrm{~kg} \mathrm{ha}^{-1}$ of $\mathrm{P}_{2} \mathrm{O}_{5}$ dose. The $\mathrm{K}$ source was the potassium chloride $\left(60 \% \mathrm{~K}_{2} \mathrm{O}\right)$ at 60 $\mathrm{kg} \mathrm{ha}^{-1}$ of $\mathrm{K}_{2} \mathrm{O}$ dose. The $\mathrm{N}$ sources used at sowing were urea $(45 \% \mathrm{~N})$ and the mono-ammonium phosphate totalizing $20 \mathrm{~kg} \mathrm{ha}^{-1}$ of $\mathrm{N}$.

Each plot consisted of four $5.5 \mathrm{~m}$ rows spaced $0.9 \mathrm{~m}$ between rows. The useful plot area consisted of the innermost rows, dropping $0.25 \mathrm{~m}$ from each end. The maize hybrid planted was 30F53YH $\left(65,000\right.$ plants ha $\left.{ }^{-1}\right)$.

\section{Leaf chlorophyll and yield}

DIAS, M. A. R. et al.

The chlorophylls $(a, b, a+b)$ estimations were performed at the third middle of the maize shoot with a chlorophyll meter model CFL 1030 Falker (Falker Agricultural Automation, Porto Alegre, Brazil), which releases results as Falker Chlorophyll Index (FCI). Five plants in each useful plot were measured in five moments during maize cycle, at 44, 55, 76, 101 and 118 days after sowing.

The chlorophyll contends in those moments were used to calculate the area under the chlorophyll progress curve (AUCPC). The AUCPC is a variable that summarizes in a value a given set of data and enables the comparison of treatments during a certain period. The AUCPC is calculated by the method of integration trapezoid in the expression described by (CAMPBELL, MADDEN, 1990):

$$
\mathrm{AUCPC}=\sum_{i=1}^{n-1}\left(\frac{y_{i}+y_{i+1}}{2}\right)\left(t_{i+1}-t_{i}\right),
$$

where: $n=$ number of assessments; $y_{i}$ and $y_{i+1}=$ values of analyzed variable observed in two consecutive assessments; $\left(t_{i+1}-t_{i}\right)=$ interval between two ratings (days).

To estimate yield the harvested ears (140 days after sowing) were dried in full sun during 5 days and threshed after drying. The grain mass obtained from the useful area $\left(9 \mathrm{~m}^{2}\right)$ was extrapolated to " $\mathrm{kg} \mathrm{ha}{ }^{-1}$ " and corrected to $13 \%$ moisture.

Statistical analysis started by checking ANOVA presumptions through the tests: homogeneity of variances (Levene test, $\mathrm{P} \leq 0.01$ ), normality of residues (Shapiro-Wilk test, $\mathrm{P} \leq 0.01$ ) and additivity (Tukey test for non-additivity, $\mathrm{P} \leq$ 0.01) using the software SPSS 16.0. After attendance of those presumptions, the ANOVA ( $F$ test, $\mathrm{P} \leq 0.05)$ was executed. The means of the $\mathrm{N}$ fertilized treatments were compared to the control treatment $\left(0 \mathrm{~kg} \mathrm{ha}^{-1} \mathrm{~N}\right)$ by Dunnet's test $(\mathrm{p} \leq 0.05)$, using Assistat software (SILVA et al., 2009). Tukey test $(\mathrm{P} \leq 0.05)$ for the factor source and analysis of polynomial regression for the factor dose, were subsequently performed using the Sisvar software (4.0) (FERREIRA, 2000).

\section{RESULTS AND DISCUSSION}

Usually, the $200 \mathrm{~kg} \mathrm{ha}^{-1} \mathrm{~N}$ dose differ (AUCPC) chlorophyll $a, b$ and $a+b$ (Table 1). The AUCPC of chlorophyll $a$ and $a+b$ increased for the doses exceeding $80 \mathrm{~kg} \mathrm{ha}^{-1}$ and $120 \mathrm{~kg} \mathrm{ha}^{-1}$ of $\mathrm{N}$ of the sources urea with NBPT and organomineral with NBPT, respectively (Table 1). For the urea polymerized source the AUCPC of the of $80 \mathrm{~kg} \mathrm{ha}^{-1}$ of $\mathrm{N}$ dose differed from the control treatment (Table $1)$. 
Table 1. Area under the chlorophyll progress curve (AUCPC) of chlorophylls $a, b$, total $(a+b)$ and production of the control treatment (no N supply) compare to other sources and doses.

\begin{tabular}{|c|c|c|c|c|c|}
\hline \multirow{2}{*}{ N SOURCE } & \multirow{2}{*}{$\begin{array}{l}\text { DOSE } \\
\mathrm{kg} \mathrm{ha}^{-1}\end{array}$} & \multicolumn{3}{|c|}{ AUCPC chlorophylls (FCI) } & \multirow{2}{*}{$\begin{array}{l}\text { PRODUCTION } \\
\mathrm{kg} \mathrm{ha}^{-1}\end{array}$} \\
\hline & & $A$ & $b$ & $a+b$ & \\
\hline \multirow{5}{*}{ Urea } & 40 & 2719.01 & 831.89 & 3550.90 & 5292.89 \\
\hline & 80 & 2658.96 & 818.88 & 3477.84 & 5688.88 \\
\hline & 120 & 2709.05 & 864.08 & 3573.13 & 6605.47 \\
\hline & 160 & 2693.91 & 842.67 & 3536.59 & 6470.13 \\
\hline & 200 & $2977.14 *$ & $1007.55 *$ & $3984.70 *$ & 6756.16 \\
\hline \multirow{5}{*}{ Urea Polymerized } & 40 & 2716.59 & 855.88 & 3572.47 & 5037.81 \\
\hline & 80 & $2756.23 *$ & $881.64^{*}$ & $3637.88^{*}$ & 5124.93 \\
\hline & 120 & 2701.81 & 820.27 & 3562.08 & 5755.86 \\
\hline & 160 & 2697.57 & 836.84 & 3534.42 & 5206.22 \\
\hline & 200 & 2710.69 & 847.22 & 3557.91 & 6600.72 \\
\hline \multirow{5}{*}{ Urea $+\mathrm{NBPT}^{1}$} & 40 & 2704.56 & 826.43 & 3530.99 & 5443.81 \\
\hline & 80 & 2697.66 & 825.75 & 3523.42 & 5189.63 \\
\hline & 120 & $2832.01 *$ & $918.12 *$ & $3750.13 *$ & 6658.61 \\
\hline & 160 & $2744.57 *$ & 863.46 & $3608.04 *$ & 6902.04 \\
\hline & 200 & $2792.01 *$ & $888.24 *$ & $3680.25^{*}$ & 4810.49 \\
\hline \multirow{5}{*}{ O.M. ${ }^{2}-\mathrm{NBPT}$} & 40 & $2765.51 *$ & 829.98 & 3595.50 & 5408.16 \\
\hline & 80 & 2638.14 & 827.72 & 3465.87 & 6222.19 \\
\hline & 120 & 2707.34 & 854.92 & 3562.27 & 6203.98 \\
\hline & 160 & 2738.96 & 843.67 & 3582.63 & 5582.29 \\
\hline & 200 & $2864.82 *$ & $930.01 *$ & $3794.83^{*}$ & 6112.49 \\
\hline \multirow{5}{*}{ O.M. + NBPT } & 40 & 2542.89 & 783.98 & 3326.87 & 6179.05 \\
\hline & 80 & 2582.33 & 766.52 & 3348.85 & 5639.51 \\
\hline & 120 & 2632.77 & 800.42 & 3433.19 & 531715 \\
\hline & 160 & $2756.72 *$ & 866.36 & $3623.09 *$ & 6896.99 \\
\hline & 200 & $2742.96^{*}$ & $916.86^{*}$ & $3659.82 *$ & 5507.95 \\
\hline Control & 0 & 2459.65 & 697.70 & 3157.36 & 5143.28 \\
\hline $\mathrm{CV}(\%)$ & & 4.94 & 9.46 & 5.88 & 21.11 \\
\hline
\end{tabular}

1 - N-(n-butyl) thiophosphoric triamide. 2 - Organomineral. Averages followed by an asterisk $(*)$ differ significantly from the control $(0$ $\mathrm{kg} \mathrm{ha}^{-1}$ ) by Dunnet's test at $5 \%$ probability.

For yield there was no difference between the treatments with $\mathrm{N}$ compared to the control (Table 1). According to Raij et al. (1997) the soil responses to $\mathrm{N}$ fertilization is expected to be low for soils after fallow periods (two or more years), soils from pasture lands, and soils intensively cultivated with leguminous species or with green manure.
The chlorophyll $a, b$ and $a+b$ for the different nitrogen sources were similar among each other (Table 2). The 'dose x AUCPC' of chlorophyll $a, b$ and $a+b$ regression model indicate the highest chlorophyll levels at the doses 211,217 and $213 \mathrm{~kg}$ ha $^{-1}$ of $\mathrm{N}$, respectively (Figure 1).

Table 2. Area under the chlorophyll progress curve (AUCPC) of chlorophylls $a, b$ e total $(a+b)$.

\begin{tabular}{llll}
\hline \multirow{2}{*}{ N SOURCE } & \multicolumn{2}{l}{ AUCPC chlorophylls (FCI) } \\
\cline { 2 - 4 } & $A$ & $b$ & $a+b$ \\
\hline UREA & $2.702 .95^{\mathrm{ns}}$ & $843.79^{\mathrm{ns}}$ & $3.546 .75^{\mathrm{ns}}$ \\
UREA POLYMERIZED $^{1}$ & 2.673 .76 & 829.93 & 3.503 .69 \\
UREIA + NBPT $^{2}$ & 2.705 .08 & 836.61 & 3.541 .70 \\
O.M. $^{2}-$ NBPT & 2.695 .73 & 830.67 & 3.526 .41 \\
O.M. + NBPT & 2.619 .55 & 805.31 & 3.424 .86 \\
\hline AVERAGE & 2.679 .41 & 829.26 & 3.508 .68 \\
CV $(\%)$ & 4.72 & 9.17 & 5.63 \\
\hline
\end{tabular}

1 - N-(n-butyl) thiophosphoric triamide. 2 - Organomineral. $n s$ : non-significant differences between sources by Tukey's test of means at $5 \%$ probability. 


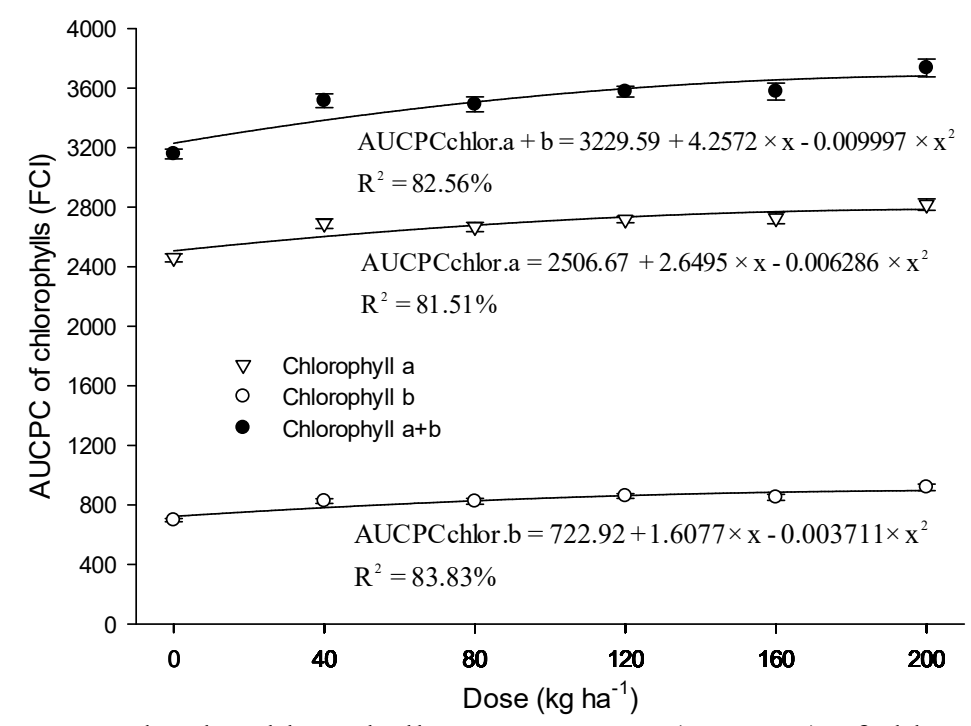

Figure 1. Graph of the area under the chlorophyll progress curve (AUCPC) of chlorophylls $a, b$, total $(a+b)$ by the doses of nitrogen.

Nitrogen participates in the composition of the chlorophylls and the assessment of the need for $\mathrm{N}$ by plants can be determined by indirect measurement of chlorophylls content (SHADCHINA, DMITRIEVA, 1995; DEBAEKE et al., 2006). The relationship between the chlorophyll assessment and the chlorophyll content in leaf, and between chlorophyll content in leaves and the $\mathrm{N}$ content in the plant are reported in literature (ARGENTA et al., 2004; SCHLEMMER et al., 2013). The results found in this study for the chlorophylls response to $\mathrm{N}$ application were positive and reached a maximum level of chlorophylls in doses around $213 \mathrm{~kg} \mathrm{ha}^{-1}$ of $\mathrm{N}$ which was similar to the responses founded by Teixeira Filho et al. (2009) in wheat.

The maize grain yield among the different $\mathrm{N}$ sources was similar, averaging $5,777 \mathrm{~kg} \mathrm{ha}^{-1}$ (Table 3). FONTOURA and BAYER (2010) also found no differences in the productivity of corn fertilized with urea or controlled release $\mathrm{N}$ sources. The $\mathrm{N}$ efficacy of the slow release, or stabilized fertilizers, compared to mineral soluble fertilizers is similar under field conditions and consequently to grain maize production (KAPPES et al., 2009; SORATTO et al., 2010; CARDOSO et al., 2011; SCHIAVINATTI et al., 2009).

Table 3. Production of grain $\left(\mathrm{kg} \mathrm{ha}^{-1}\right)$ for the different nitrogen sources.

\begin{tabular}{ll}
\hline N SOURCE & $\begin{array}{l}\text { PRODUCTION } \\
\mathrm{kg} \mathrm{ha}^{-1}\end{array}$ \\
\hline UREA & $5992.80^{\text {ns }}$ \\
UREA POLYMERIZED & 5478.14 \\
UREIA + NBPT $^{1}$ & 5691.31 \\
O.M. $^{2}$ - NBPT & 5778.73 \\
O.M. + NBPT & 5780.66 \\
\hline AVERAGE & 5744.33 \\
CV $(\%)$ & 21.19 \\
\hline
\end{tabular}

1 - N-(n-butyl) thiophosphoric triamide. 2 - Organomineral. ns: non-significant differences between sources by Tukey's test of means at $5 \%$ probability.

The maize grain yield, for any of the sources evaluated, raises about $4.87 \mathrm{~kg} \mathrm{ha}^{-1}$ per each kilogram of $\mathrm{N}$ from (Figure 2), reaching up to 5,993 $\mathrm{kg} \mathrm{ha}^{-1}$ of grain (Table 3). The low yield response to
$\mathrm{N}$ fertilization caused by the immobilization of nitrogen probably affected the productive potential of the plant and, consequently, the productivity obtained in this work (Table 3). 


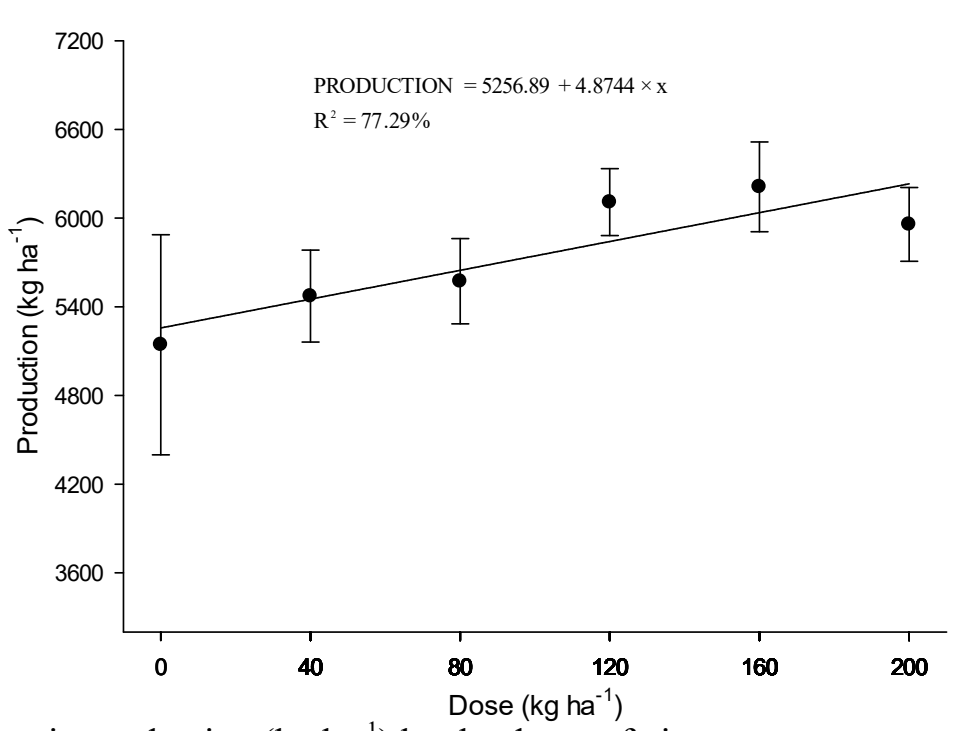

Figure 2. Graph of the grain production $\left(\mathrm{kg} \mathrm{ha}^{-1}\right)$ by the doses of nitrogen.

Andrade et al. (2014), Soratto et al., (2010) and Kappes et al. (2009) also found significant responses in maize grain yield, regardless of the $\mathrm{N}$ source, with the application of doses up to 134, 120 and $70 \mathrm{~kg} \mathrm{ha}^{-1}$ of $\mathrm{N}$, respectively. Linear responses of maize grain yield were also observed in studies of Sichocki et al. (2014) and Valderrama et al. (2014).

According to Fageria et al. (2013) the N, further than a component of chlorophylls, is also associated to leaf area increases, high solar radiation interception efficiency and photosynthetic rate, consequently improving grain yield, justifying higher yields where there was an application of higher $\mathrm{N}$ doses.

\section{CONCLUSIONS}

There were no significant differences for the different $\mathrm{N}$ sources, indicating that the organomineral source is as efficient as the mineral source.

The increasing doses of $\mathrm{N}$ fertilizers, regardless of the source used, increased the levels of chlorophylls and grain yield.

\section{ACKNOWLEDGEMENTS}

To CAPES and to the Support Program for Qualification of UFU, by the financial aid. To all faculty and staff members of the Graduate Program in Agricultural Engineering from UFU.

RESUMO: O nitrogênio (N) é um dos nutrientes absorvidos em grande quantidade pela cultura do milho. Além disso, os fertilizantes nitrogenados são de alto custo e sujeitos a grandes perdas no ambiente agrícola. Existem várias categorias de fertilizantes, conhecidas como fertilizantes de maior eficiência, que podem minimizar essas perdas de $\mathrm{N}$. O objetivo deste estudo foi avaliar o efeito de diferentes fontes e doses de $\mathrm{N}$ no desempenho agronômico do milho. $\mathrm{O}$ experimento foi instalado em blocos casualizados, com quatro repetições, delineadas como fatorial $5 \times 5+1$, constituído por cinco fontes de $\mathrm{N}$ (uréia, uréia polimerizada, uréia com NBPT, organomineral com e sem NBPT), cinco doses de N (40,80,120,160, $\left.200 \mathrm{~kg} \mathrm{ha}^{-1}\right)$ mais um controle (sem fornecimento de N). O conteúdo de clorofila e o rendimento de grãos foram avaliados. Os resultados não mostraram diferenças para as diferentes fontes de $\mathrm{N}$, indicando que as fontes organomineral são tão eficientes quanto as fontes minerais. A adição de fertilizantes $\mathrm{N}$ em doses crescentes, independentemente da fonte testada, aumentou os níveis de clorofilas e rendimento de grãos .

PALAVRAS-CHAVE: Zea mays $L$.. Tecnologia de fertilizantes. Rendimento de grãos. Uréia. Organomineral. 


\section{REFERENCES}

ALVA, A. K.; PARAMASIVAM, S.; FARES, A.; DELGADO, J. A.; MATTOS, Jr, D.; SAJWAN, K. Nitrogen and irrigation management practices to improve nitrogen uptake efficiency and minimize leaching losses.

Journal of Crop Improvement, v. 15, n. 2, p. 369-420. 2005. https://doi.org/10.1300/J411v15n02_11

ALVARES, C. A.; STAPE, J. L.; SENTELHAS, P. C.; GONÇALVES, J. L. M.; SPAROVEK, G. 2013. Köppen's climate classification map for Brazil. Meteorologische Zeitschrift (english). v. 22, n. 6, p. 711-728. https://doi.org/10.1127/0941-2948/2013/0507

ALVES, V. M. C.; VASCONCELLOS, C. A.; FREIRE, F. M.; PITTA, G. V. E.; FRANÇA, G. E.; RODRIGUES FILHO, A.; ARAÚJO, J. M.; VIEIRA, J. R.; LOUREIRO, J. E. Milho. In: RIBEIRO, A. C.; GUIMARÃES, P. T. G.; ALVAREZ VENEGAS, V. H. (Ed.). Recomendações para o uso de corretivos e fertilizantes em Minas Gerais: 5a aproximação. Viçosa: Comissão de Fertilidade do Solo do Estado de Minas Gerais, 1999. p. 314-316.

ARGENTA, G.; SILVA, P. R. F.; SANGOI, L. 2004. Leaf relative chlorophyll content as an indicator parameter to predict nitrogen fertilization in maize. Ciência Rural, v. 34, n. 5, p. 1379-1387.

https://dx.doi.org/10.1590/S0103-84782004000500009

BÜLL, L. T. Nutrição mineral do milho. In: BÜLL, L. T.; CANTARELLA, H. (Ed.). Cultura do milho: Fatores que afetam a produtividade. Potafós, 1993. p. 63-145.

CAMPBELL, C. L.; MADDEN, L. V. Introduction to plant disease epidemiology. 1990. 532 p.

CARDOSO, S. M.; SORATTO, R. P.; SILVA, A. H.; MENDONÇA, C. G. Fontes e parcelamento do nitrogênio em cobertura, na cultura do milho sob plantio direto. Revista Brasileira de Ciências Agrárias, v. 6, n. 1, p. 23-28. 2011.

DEBAEKE, P.; ROUET, P.; JUSTES, E. Relationship between the normalized SPAD index and the nitrogen nutrition index: application to Durum Wheat. Journal of Plant Nutrition, v. 29, p. 75-92. 2006.

https://doi.org/10.1080/01904160500416471

EMBRAPA - Empresa Brasileira de Pesquisa Agropecuária. Centro Nacional de Pesquisas de Solos. Manual de métodos de análises de solos. 2.ed. Rio de Janeiro: Embrapa Solos, 2011.230p.

EMBRAPA - Empresa Brasileira de Pesquisa Agropecuária. Sistema brasileiro de classificação de solos. 3. ed. Brasília: Embrapa, 2013. 353 p.

FAGERIA, N. K.; SANTOS, A. B.; STONE, L. F. Manejo de nitrogênio em arroz irrigado. Santo Antônio de Goiás: Embrapa, 2003. (Circular técnica, 58).

FERREIRA, D. F. Análises estatísticas por meio do Sisvar para o Windows versão 4.0. In: Reunião Anual da Região Brasileira da Sociedade Internacional Biometria. Anais., São Paulo: UFSCAR, 2000. p. 255-258.

FONTOURA, S. M. V.; BAYER, C. Ammonia volatilization in no-till system in the south-central region of the State of Paraná, Brazil. Revista Brasileira de Ciência do Solo, v. 34, n. 5, p. 1677-1684. 2010. http://dx.doi.org/10.1590/S0100-06832010000500020

KAPPES, C.; CARVALHO, M. A. C.; YAMASHITA, O. M.; SILVA, J. A. N. Influência do nitrogênio no desempenho produtivo do milho cultivado na segunda safra em sucessão à soja. Pesquisa Agropecuária Tropical, v. 39, n. 3, p. 251-259. 2009.

KRAJEWSKA, B. 2009. Ureases I. Functional, catalyctic and kinetic properties: A review. Journal of Molecular Catalysis B: Enzimatic, 59:09-21. https://doi.org/10.1016/j.molcatb.2009.01.003 
LARA CABEZAS, W. A. R.; TRIVELIN, P. C. O.; KONDÖRFER, G. H.; PEREIRA, S. Balanço da adubação nitrogenada sólida e fluida de cobertura na cultura do milho, em sistema plantio direto no triângulo mineiro (MG). Revista Brasileira de Ciência do Solo, v. 24, p. 363-376. 2000.

RAIJ, B. Van.; CANTARELLA, H.; QUAGGIO, J. A.; FURLANI, A. M. C. Recomendações de adubação e calagem para o Estado de São Paulo. (Boletim Técnico, 100), 2.ed. Campinas: IAC, 1997. 285 p.

SCHIAVINATTI, A. F. ANDREOTTI, M.; BENETT, C. G. S.; PARIZ, C. M.; LODO, B. N.; BUZETTI, S. Influência de fontes e modos de aplicação de nitrogênio nos componentes da produção e produtividade do milho irrigado no cerrado. Bragantia, v. 70, n. 4, p. 295-230. 2011. http://dx.doi.org/10.1590/S000687052011000400027

SCHLEMMER, M.; GITELSON, A.; SCHEPERS, J.; FERGUNSON, R.; PENG, Y.; SHANAHAN, J.;

RUNDQUIST, D. 2013. Remote estimation of nitrogen and chlorophyll contents in maize at leaf and canopy levels. International Journal of Applied Earth Observation and Geoinformation, v. 25, p. 47-54. https://doi.org/10.1016/j.jag.2013.04.003

SHADCHINA, T.M.; DMITRIEVA, V.V. Leaf chlorophyll content as a possible diagnostic mean for the evalution of plant nitrogen uptake from the soil. Journal of Plant Nutrition, v. 18, p. 1427-1437. 1995. https://doi.org/10.1080/01904169509364992

SICHOCKI, D.; GOTT, R. M.; FUGA, C. A. G.; AQUINO, L. A.; RUAS, R. A. A.; NUNES, P. H. M. P. Resposta do milho safrinha a doses de nitrogênio e fósforo. Revista Brasileira de Milho e Sorgo. v. 13, n. 1, 2014.

SILVA, F. DE A. S. E.; AZEVEDO, C. A. V. Principal components analysis in the software AssistatStatistical attendance. In: World Congress on Computers in Agriculture, 7, Reno-NV-USA: American Society of Agricultural and Biological Engineers, 2009.

SILVA, E. C.; BUZETTI, S.; GUIMARÃES, G. L.; LAZARINI, E.; SÁ, M. E. Doses e épocas de aplicação de nitrogênio na cultura do milho em plantio direto sobre Latossolo Vermelho. Revista Brasileira de Ciência do Solo, v. 29, n. 3, p. 353-362. 2005. http://dx.doi.org/10.1590/S0100-06832005000300005

SORATTO, R. P.; PEREIRA, M.; COSTA, T. A. M.; LAMPERT, V. N. Fontes alternativas e doses de nitrogênio no milho safrinha em sucessão a soja. Revista Ciência Agronômica, v. 41, n. 4, p. 511-518. 2010. http://dx.doi.org/10.1590/S1806-66902010000400002

TEIXEIRA FILHO, M. C. M.; BUZETTI, S.; ANDREOTTI, M.; SÁ, M. E. de; ARF, O.; MEGDA, M. M. Response of irrigated wheat cultivars to different nitrogen rates and sources. Revista Brasileira de Ciência do Solo, v. 33, p. 1303-1310. 2009. http://dx.doi.org/10.1590/S0100-06832009000500023

TRENKEL, M. E. Slow-and controlled-release and stabilized fertilizers: An option for enhancing nutrient use efficiency in agriculture. Paris: International Fertilizer Industry Association, 2010. 163 p.

VALDERRAMA, M.; BUZETTI, S.; TEIXEIRA FILHO, M. C. M.; BENETT, C. G. S.; ANDREOTT, M. Adubação nitrogenada na cultura do milho com ureia revestida por diferentes fontes de polímeros. Semina: Ciências Agrárias, v. 35, n. 2, p. 659-670. 2014. https://dx.doi.org/10.5433/1679-0359.2014v35n2p659 